\title{
Correction to: Schwannoma gene therapy by adeno-associated virus delivery of the pore-forming protein Gasdermin-D
}

\author{
Sherif G. Ahmed ${ }^{1} \cdot$ Ahmed Abdelanabi $^{1} \cdot$ Mohamed Doha $^{1} \cdot$ Gary J. Brenner ${ }^{1}$
}

Published online: 6 May 2019

(c) Springer Nature America, Inc. 2019

\section{Correction to: Cancer Gene Therapy}

https://doi.org/10.1038/s41417-018-0077-3

Published online 9 January 2019
The original version of this Article contained an error in the spelling of the author Ahmed Abdelnabi, which was incorrectly given as Abdelnabi Ahmed. This has now been corrected in both the PDF and HTML versions of the Article. 